\title{
Erratum to: Effect of Chromium Supplementation on Productive and Reproductive Performances and Some Metabolic Parameters in Late Gestation and Early Lactation of Dairy Cows
}

\author{
F. Kafilzadeh • H. Karami shabankareh • M. R. Targhibi
}

Published online: 14 July 2012

(C) Springer Science+Business Media, LLC 2012

Erratum to: Biol Trace Elem Res

DOI 10.1007/s12011-012-9390-0

The original version of this article unfortunately contained a typing mistake in the formula given for $4 \% \mathrm{FCM}$ under the Table 1 . The correct formula used for calculation of $4 \% \mathrm{FCM}$ was " $4 \% \mathrm{FCM}=[($ yield $\times 0.4)+($ fat yield $\times 15)$. The Original formula $" 4 \% \mathrm{FCM}=[($ yield $\times 0.4)+($ yield $\times$ fat yield $) \times 15]$ is incorrect and should be deleted.

The online version of the original article can be found at http://dx.doi.org/ 10.1007/s12011-012-9390-0.

F. Kafilzadeh $(\bowtie) \cdot H$. K. shabankareh $\cdot$ M. R. Targhibi Department of Animal Science, Faculty of Agriculture, Razi University,

Kermanshah 6719685416, Iran

e-mail: kafilzadeh@razi.ac.ir

H. K. shabankareh

e-mail: hkaramishabankareh@yahoo.com

M. R. Targhibi

e-mail: m.r.targhibi@gmail.com 